\title{
UJI DAYA HAMBAT EKSTRAK ETANOL UMBI HATI TANAH (Angiotepris Sp.) TERHADAP BAKTERI Staphylococcus aureus
}

\author{
Susi Novaryatiin ${ }^{1}$, Rezqi Handayani ${ }^{1,}$ Rizqi Chairunnisa ${ }^{2}$ \\ 'Dosen Program Studi D-III Farmasi Universitas Muhammadiyah Palangkaraya \\ ${ }^{2}$ Mahasiswa Program Studi D-III Farmasi Fakultas IImu Kesehatan Universitas \\ Muhammadiyah Palangkaraya \\ Email : susi novaritaiin@yahoo.com, rezqi.handayani@gmail.com, \\ riz1ichacha@yahoo.co.id
}

\begin{abstract}
ABSTRAK
Kalimantan merupakan pulau di Indonesia yang terkenal dengan keanekaragaman hayatinya.Potensi tumbuhan obat di hutan Kalimantan adalah terbesar di berbagai kawasan hutan dengan tingkat keanekaragaman yang tinggi, beragam habitus, dan bagian yang digunakan.Pemanfaatan tumbuhan sebagai obat tradisional bukanlah hal yang baru, dan telah dikenal masyarakat secara luas sejak zaman dahulu.Saat ini penggunaan obat-obatan yang berasal dari tanaman banyak diminati, meskipun telah banyak beredar obat jadi yang merupakan senyawa sintesis. Hal ini dibuktikan dengan adanya kecenderungan masyarakat global untuk kembali ke alam (back to nature) dalam bidang penyediaan obat-obatan.

Tumbuhan Hati Tanah adalah salah satu tumbuhan obat yang memiliki manfaat sebagai obat tradisional dan digunakan oleh masyarakat Kota Palangka Raya, Provinsi Kalimantan Tengah.Secara empiris umbi tumbuhan ini dipercaya dapat mengobati luka, luka pasca melahirkan, malaria, dan diare.Maka dari itu, penelitian ini mengangkat khasiat empiris umbi Hati Tanah sebagai obat luka. Penelitian ini dilakukan dengan cara pengujian aktivitas antibakteri ekstrak etanol umbi Hati Tanah pada konsentrasi 1\%, 5\%, 10\%, dan 15\% dengan metode Kirby-Bauer yaitu metode difusi dengan menggunakan kertas cakram (disc) sedangkan proses ekstraksi dilakukan dengan metode sokhletasi dan pelarut etanol $96 \%$. Pengukuran zona hambat ini dilakukan dengan cara mengambil garis horizontal pada zona bening di sekitar disc menggunakan jangka sorong. Rata-rata hasil pengukuran zona hambat ekstrak etanol umbi Hati Tanah pada konsentrasi 1\%, 5\%, 10\%, dan 15\% berturut-turut 15,63 $\pm 0,15 \mathrm{~mm}$, $16,97 \pm 0,20 \mathrm{~mm}, 25,43 \pm 0,20 \mathrm{~mm}$, dan $28,40 \pm 0,20 \mathrm{~mm}$. Sedangkan rata-rata zona hambat pada kontrol positif yaitu Tetrasiklin dengan konsentrasi $1 \%, 5 \%, 10 \%$, dan $15 \%$ secara berurut yaitu 12,93 \pm 0,15 mm, 16,07 $\pm 0,15 \mathrm{~mm}, 16,83 \pm 0,35 \mathrm{~mm}$, dan 22,07 $\pm 0,25 \mathrm{~mm}$.

Berdasarkan Clinical Laboratory Standart Institute (CLSI), hasil zona hambat antibiotik yang diujikan pada konsentrasi $1 \%$ dikategorikan resistant, konsentrasi $5 \%$ dan 10\% dikategorikan intermediate, dan konsentrasi $15 \%$ dikategorikan susceptible. sedangkan zona hambat yang dihasilkan oleh ekstrak etanol umbi Hati Tanah pada konsentrasi 1\% dan 5\% dapat dikategorikan intermediate sedangkan pada konsentrasi $10 \%$ dan 15\% dapat diinterpretasikan ke dalam kategori susceptible. Hasil ini menunjukkan bahwa ekstrak etanol umbi Hati Tanah berpotensi menghambat pertumbuhan bakteri Staphylococcus aureus, namun perlu dilakukan penelitian lebih lanjut menggunakan interval konsentrasi yang lebih tinggi.
\end{abstract}

Kata Kunci : Uji Daya Hambat, Ekstrak Etanol Umbi Hati Tanah, Staphylococcus aureus. 


\section{PENDAHULUAN}

Pemanfaatan tumbuhan sebagai obat tradisional bukanlah hal yang baru, dan telah dikenal masyarakat secara luas sejak zaman dahulu.Saat ini penggunaan obat-obatan yang berasal dari tanaman banyak diminati, meskipun telah banyak beredar obat jadi yang merupakan senyawa sintesis.Hal ini dibuktikan dengan adanya kecenderungan masyarakat global untuk kembali ke alam (back to nature) dalam bidang penyediaan obat-obatan.

Ketergantungan dunia pada tumbuhan obat cukup tinggi.Semakin banyak perusahaan farmasi di negara industri dan mengembangkan produknya dengan menggunakan bahan dasar dari alam. Sekitar 25\% farmasi dunia mengembangkan produk obat-obatan dengan bahanbaku dari tumbuhan. Hal ini membuktikan bahwa tumbuhan obat sangat penting untuk obat modern. Perusahaan farmasi di negara-negara maju umumnya tidak memiliki sumber bahan baku yang cukup. Mereka melakukan eksplorasi secara agresif ke negara-negara yang memiliki hutan tropis dengan kekayaan keanekaragaman hayati yang tinggi untuk mengambil dan meneliti tumbuhan obat yang dinilai memiliki nilai penting untuk obat modern, dan memanfaatkan pengetahuan adat setempat tentang penggunaannya (Wijayakusuma, 2007).
Indonesia merupakan salah satu negara yang memiliki hutan tropis terbesar di dunia. Hutan tropis yang sangat luas dengan kekayaan keanekaragaman hayati di dalamnya merupakan sumber daya alam dan gudang tumbuhan obat, sehingga dunia menjuluki Indonesia sebagai live laboratory (Wijayakusuma, 2007). Hal tersebut karena Indonesia memiliki 30.000 spesies tumbuhan, dari jumlah tersebut sekitar 9.600 spesies diketahui berkhasiat obat, dan baru 200 spesies yang telah dimanfaatkan sebagai bahan baku pada industri obat tradisional (Hapsoh dan Hasanah, 2011).

Kalimantan merupakan pulau di Indonesia yang terkenal dengan keanekaragaman hayatinya.Tak hanya itu, pengetahuan pengobatan tradisional dengan menggunakan tumbuhan yang diwariskan secara lisan dari generasi ke generasi pada etnis asli di Kalimantan juga sangat banyak.Potensi tumbuhan obat di hutan Kalimantan adalah terbesar di berbagai kawasan hutan dengan tingkat keanekaragaman yang tinggi, beragam habitus, dan bagian yang digunakan (Noorhidayah dan Sidiyasa, 2005).

Di sisi lain, Kalimantan Tengah dengan luas wilayah mencapai 15.380.410 Ha termasuk salah satu kawasan yang juga banyak menyimpan keanekaragaman hayati untuk plasma nutfah tumbuhan obat (Krismawati dan Sabran, 2006). 
Diperkirakan beribu-ribu jenis tumbuhan obat belum ditemukan dan dibudidayakan. Menurut Hartini dan Dwi (2005) dalam Handayani et al. (2005) melingkupi beberapa jenis baru (spesies nova), catatan baru (new record), ataupun lokasi baru (new spot). Provinsi ini merupakan asal berbagai tanaman obat seperti Tabat Barito, Akar Kuning, Pasak Bumi dan beberapa tanaman obat lainnya yang berguna untuk kesehatan manusia.

Salah satu tumbuhan obat yang memiliki manfaat sebagai obat tradisional dan digunakan oleh masyarakat Kota Palangka Raya, Provinsi Kalimantan Tengah adalah tumbuhan Hati Tanah.Secara empiris umbi tumbuhan ini dipercaya dapat mengobati luka, luka pasca melahirkan, malaria, dan diare. Berdasarkan pengalaman empiris tersebut, beberapa peneliti telah melakukan penelitian mengenai umbi tumbuhan Hati Tanah, namun masih hanya sebatas pengujian farmakognostik dan aktivitas sebagai antimalaria, sedangkan manfaat dalam penyembuhan gangguan pencernaan dan masalah pada kulit belum dilakukan penelitian lebih lanjut. Maka dari itu, penelitian ini akan mengangkat khasiat empiris umbi Hati Tanah sebagai obat luka.

Luka adalah kerusakan struktur anatomi kulit yang menyebabkan gangguan kulit.Kulit merupakan salah satu panca indera manusia yang terletak di permukaan
tubuh.Berkaitan dengan letaknya yang ada di permukaan tubuh maka kulit merupakan organ pertama yang terkena pengaruh tidak menguntungkan dari lingkungan (Santoso, 2001).Kulit mempunyai bermacam-macam fungsi dan kegunaan, diantaranya kulit berfungsi sebagai termostat dalam mempertahankan suhu tubuh, melindungi tubuh dari serangan mikroorganisme, sinar ultraviolet, dan berperan pula dalam mengatur tekanan darah (Lachman et al., 1994).Secara alamiah kulit telah berusaha untuk melindungi diri dari serangan mikroorganisme dengan adanya tabir lemak di atas kulit yang diperoleh dari kelenjar lemak dan sedikit kelenjar keringat dari kulit serta adanya lapisan kulit luar yang berfungsi sebagai sawar kulit (Wasitaatmadja, 1997).Namun dalam kondisi tertentu faktor perlindungan alamiah tersebut tidak mencukupi dan seringkali akibat bakteri yang melekat pada kulit menyebabkan terjadinya infeksi, terutama pada kulit yang terluka.

$$
\text { Salah satu bakteri yang }
$$
menyebabkan infeksi pada kulit yang terluka adalah bakteri Staphylococcus aureus (Sim dan Romi, 2009).Staphylococcus aureus merupakan bakteri gram positif berbentuk bulat tersusun seperti buah anggur.Bakteri ini diperkirakan ditemukan pada saluran pernapasan atas, muka, tangan, dan rambut.Diantara organ yang sering diserang 
oleh Staphylococcus aureus adalah kulit yang mengalami luka (Amalia, 2016).

Pengobatan terhadap infeksi Staphylococcus aureus dilakukan dengan pemberian antibiotik.Sejak ditemukan zat antimikroba, banyak zat-zat yang terbukti efektif melawan bakteri, dan mikroba patogen.Namun, perkembangan mikroba patogen dapat membentuk suatu sistem kekebalan atau resistensi terhadap satu atau lebih jenis antibiotik.Resistensi antibiotik bisa terjadi melalui 3 mekanisme yaitu obat tidak dapat mencapai tempat kerjanya, inaktivasi obat dan mikroba mengubah tempat ikatan antibiotik (Hamzah, 2012 dalam Lombogia et al., 2016).

Berdasarkan hal di atas, maka sangat masuk akal untuk beranggapan bahwa antibiotik-antibiotik yang baru hanya akan menunda masalah, dan pada saatnya nanti bakteri akan menjadi kebal terhadap antibiotik tersebut. Oleh karena itu para ilmuan medis terutama di Eropa dan Asia memilih penelitian dari antibiotik senyawa tunggal ke antibiotik senyawa kompleks yang berasal dari ekstrak tumbuhan obat. Hal ini terjadi karena pada ekstrak tumbuhan obat ditemukan puluhan bahkan ratusan senyawa aktif yang memiliki fungsi yang sama maupun yang berlainan (immune-stimulan, antioksidan, bakterisidal, bakteriostatik, sinergisasi antibiotik sintetik, dan lain sebagainya) namun dapat bekerja secara harmonis melawan suatu infeksi (Green, 2005 dalam Lombogia et al., 2016).

Tumbuhan Hati Tanah dipercaya berkhasiat menyembuhkan masalah kulit seperti luka, hal ini sejalan dengan adanya beberapa senyawa aktif yang diduga memiliki bioaktivitas sebagai antibakteri.Berdasarkan penelitian Handayani et al. (2015), simplisia umbi tumbuhan Hati Tanah positif mengandung Flavonoid, Tanin, Katekol, dan Saponin.Salah satu kandungan metabolit sekunder yang berperan sebagai antibiotik adalah flavonoid.

\section{METODELOGI PENELITIAN}

Penelitian ini dilaksanakan di laboratorium Mikrobiologi dan Farmakognosi Fakultas IImu Kesehatan Universitas Muhammadiyah Palangkaraya. Waktu penelitian ini selama 2 bulan, kegiatan penelitian ini dimulai dari pengambilan tumbuhan Kelakai, pembuatan ekstrak dan uji daya hambat ekstrak etanol akar Umbi Hati Tanah (Angiotepris Sp) terhadap bakteri Staphylococcus aureus.

\section{Ekstraksi}

Rimpang umbi Hati tanah diekstraksi dengan cara sokhletasi. Caranya adalah dengan membuat simplisia dari sampel umbi Hati Tanag kemudian dibuat serbuk sesuai dengan derajat serbuk yang ditentukan, yaitu tidak terlalu halus. Menimbang serbuk rimpang lengkuas sebanyak $100 \mathrm{mg}$. Memasukkan serbuk 
umbi Hati Tanah ke dalam alat sokhletasi. Menambahkan pelarut etanol $96 \%$ hingga serbuk terendam, kemudian merangkaikan alat sokhletasi dan dibiarkan sampel hingga ekstrak cair pada labu rumah siput tidak berwarna (bening).Mengambil ekstrak cair yang didapat kemudian menguapkan hingga diperoleh ektrak kental sampel umbi Hati tanah. Selanjutnya menimbang ekstrak kental yang didapat.

\section{Uji Daya Hambat}

Media EMB sebnayak $10 \mathrm{ml}$ dituang ke dalam cawan petri dan dibiarkan mamadat, kemudian memasukkan suspensi bakteri Staphylococcus aureus dengan menggunakan lidi kapas setril agar suspensi terserap pada media.Kemudian di dalam cawan petri tersebut diletakkan disk yang sebelumnya telah direndam dengan larutan kontrol positif (Tetrasiklin) dan sampel uji (ekstrak etanol umbi Hati Tanah) sesuai dengan konsentrasinya yaitu $1 \%, 5 \%$ dan $10 \%$ menggunakan pinset steril.Perlakuan dilakukan secara triplo untuk memastikan hasil yang didapat.Selanjutnya semua media diinkubasi ke dalam incubator.Inkubasi dilakukan pada suhu $37^{\circ} \mathrm{C}$ selama 24 jam.Kemudian diukur diameter zona bening yang terbentuk dengan menggunakan penggaris millimeter.Aktivitas antibakteri diperoleh dengan mengukur zona bening pada media yang padat dan menjadi petunjuk ada atau tidaknya bakteri yang tumbuh pada setiap perlakukan.

\section{HASIL DAN PEMBAHASAN Ekstraksi Umbi Hati Tanah}

Ekstrak kental umbi Hati Tanah yang didapat dari ekstraksi dengan metode sokhletasi sebanyak 23,7343. Penggunaan alat sokhlet pada saat proses ekstraksi dikarenakan zat aktif yang terdapat pada umbi Hati Tanah dapat tersari sempurna apabila disertai dengan pemanasan, hal ini disebabkan karena umbi memiliki kadar air yang tinggi meskipun telah diolah menjadi simplisia, sehingga apabila proses ekstraksi dilakukan dengan proses pemanasan maka akan mempercepat proses pengolahan ekstrak. Prinsip sokhletasi adalah penyarian secara terus-menerus dan pelarut yang digunakan akan mengalami sirkulasi sehingga penyarian lebih sempurna dengan menggunakan pelarut dalam jumlah kecil. Pengamatan sederhana sebagai indikator berakhirnya proses ekstraksi adalah pelarut pada labu rumah siput telah tidak menunjukkan warna (bening). Pelarut yang digunakan pada proses ekstraksi ini adalah etanol 96\%, menurut Harborne (1987) dalam Mustarichie et al. (2016), pelarut etanol dipilih karena etanol merupakan pelarut universal yang mampu melarutkan hampir seluruh jenis metabolit sekunder yang terkandung dan tidak bersifat racun serta aman untuk digunakan. Dengan kemampuannya menarik senyawa berdasarkan tingkat kepolaran, termasuk 
senyara non polar dan protein yang terkandung sehingga akan menghambat reaksi enzimatik dan mencegah terjadinya hidrolisis serta oksidasi, itulah alasan mengapa digunakannya etanol.

\section{Uji Daya Hambat Umbi Hati Tanah}

Pada uji daya hambat menggunakan 5 sampel yaitu control

Tabel 1.Hasil Pengukuran Zona Hambat Dibandingkan dengan CLSI

\begin{tabular}{|c|c|c|c|c|c|c|}
\hline \multirow{2}{*}{ Uji } & \multirow{2}{*}{$\begin{array}{c}\text { Konsentrasi } \\
(\%)\end{array}$} & \multicolumn{3}{|c|}{ Percobaan (mm) } & \multirow{2}{*}{$\begin{array}{l}\text { Rata-Rata } \\
\pm \mathrm{SD}(\mathrm{mm})\end{array}$} & \multirow{2}{*}{$\begin{array}{c}\text { Interpretasi } \\
\text { Daya Hambat }\end{array}$} \\
\hline & & I & II & III & & \\
\hline \multirow{4}{*}{$\begin{array}{c}\text { Kontrol } \\
\text { Positif } \\
\text { Tetrasiklin }\end{array}$} & $1 \%$ & 12,8 & 12,9 & 13,1 & $12,93 \pm 0,15$ & Resistant \\
\hline & $5 \%$ & 15,9 & 16,1 & 16,2 & $16,07 \pm 0,15$ & Intermediate \\
\hline & $10 \%$ & 16,5 & 16,8 & 17,2 & $16,83 \pm 0,35$ & Intermediate \\
\hline & $15 \%$ & 21,8 & 22,1 & 22,3 & $22,07 \pm 0,25$ & Susceptible \\
\hline \multirow{4}{*}{$\begin{array}{c}\text { Ekstrak } \\
\text { Etanol } \\
\text { Umbi Hati } \\
\text { Tanah }\end{array}$} & $1 \%$ & 15,5 & 15,8 & 15,6 & $15,63 \pm 0,15$ & Intermediate \\
\hline & $5 \%$ & 16,8 & 17,2 & 16,9 & $16,97 \pm 0,20$ & Intermediate \\
\hline & $10 \%$ & 25,5 & 25,2 & 25,6 & $25,43 \pm 0,20$ & Susceptible \\
\hline & $15 \%$ & 28,4 & 28,2 & 28,6 & $28,40 \pm 0,20$ & Susceptible \\
\hline
\end{tabular}

Sumber : Data Primer, 2017

Keterangan :

* SD = Standar Deviasi

* Interpretasi Daya Hambat (CLSI, 2013),

$\leq 14 \mathrm{~mm}=$ Resistant

$15-18 \mathrm{~mm}=$ Intermediate

$\geq 19 \mathrm{~mm}=$ Susceptible

Pengujian ekstrak etanol umbi Hati Tanah dilakukan dengan 4 konsentrasi yaitu positifnya adalah Tetrasiklindan sampel ujinya adalah ekstrak kental etanol umbi Hati Tanah. Konsentrasi larutan untuk masing-masing sampel adalah 1\%, $5 \%$ dan $10 \%$.Dari penelitian yang dilakukan didapatkan hasil uji daya hambat yang dapat dilihat pada Tabel 1. 
pengamatan dengan fokus kepada konsentrasi terendah yang masih poten untuk menghambat pertumbuhan mikroorganisme. Hasil penelitian ini menunjukkan adanya daya hambat dari ekstrak etanol umbi Hati Tanah terhadap pertumbuhan bakteri Staphylococcus aureus yang ditanam pada MHA setelah proses inkubasi pada suhu $37^{\circ} \mathrm{C}$ selama 24 jam. Kemampuan daya hambat tersebut ditandai dengan terbentuknya zona bening di sekitar disc.

Berdasarkan hasil pengamatan yang dilakukan sebanyak 3 kali pengulangan, ekstrak etanol umbi Hati Tanah menunjukkan adanya zona hambat yang bervariasi. Rata-rata hasil pengukuran zona hambat ekstrak etanol umbi Hati Tanah pada konsentrasi $1 \%, 5 \%, 10 \%$, dan $15 \%$ berturut-turut $15,63 \pm 0,15 \mathrm{~mm}, 16,97 \pm$ $0,20 \mathrm{~mm}, 25,43 \pm 0,20 \mathrm{~mm}$, dan 28,40 \pm $0,20 \mathrm{~mm}$. Semakin tinggi konsentrasi ekstrak etanol umbi Hati Tanah maka semakin besar zona hambat yang dihasilkan. Jika dibandingkan dengan ketentuan pada CLSI, maka zona hambat yang dihasilkan oleh ekstrak etanol umbi Hati Tanah pada konsentrasi 1\% dan 5\% dapat dikategorikan intermediate sedangkan pada konsentrasi $10 \%$ dan $15 \%$ dapat diinterpretasikan ke dalam kategori susceptible.

Selain itu, penelitian ini juga menggunakan kontrol positif yang berguna sebagai pembanding atau tolak ukur dalam menentukan kemampuan ekstrak dalam menghambat bakteri.Dalam penelitian ini, kontrol positif yang digunakan adalah Tetrasiklin, hal ini didasari dengan adanya indikasi antibiotik tersebut yang dapat digunakan sebagai antibakteri baik bagi bakteri gram positif maupun bakteri gram negatif.Disamping itu, antibiotik tersebut dapat digunakan sebagai sediaan topikal guna mengatasi infeksi pada kulit, khususnya pada kulit yang terluka. Konsentrasi Tetrasiklin yang digunakan adalah $1 \%, 5 \%, 10 \%$, dan $15 \%$ sehingga diperoleh zona hambat secara berurut yaitu $12,93 \pm 0,15 \mathrm{~mm}, 16,07 \pm 0,15 \mathrm{~mm}, 16,83 \pm$ $0,35 \mathrm{~mm}$, dan 22,07 $\pm 0,25 \mathrm{~mm}$. Berdasarkan CLSI, hasil zona hambat antibiotik yang diujikan pada konsentrasi $1 \%$ dikategorikan resistant, konsentrasi $5 \%$ dan $10 \%$ dikategorikan intermediate, dan konsentrasi $15 \%$ dikategorikan susceptible. Pengukuran zona hambat ini dilakukan dengan cara mengambil garis horizontal pada zona bening di sekitar disc menggunakan jangka sorong.

Hasil berupa zona bening yang terbentuk dikarenakan terdapat kandungan senyawa aktif pada umbi Hati Tanah berupa flavonoid yang berperan sebagai antibakteri sehingga dapat menghambat pertumbuhan bakteri. Menurut Sulistyawati dan Mulyati (2009) dalam Haerazi et al. (2016), flavonoid bekerja dengan 
menghambat pembelahan atau proliferasi sel bakteri.Senyawa ini mengikat protein pada mikrotubulus dalam sel dan mengganggu fungsi mitosis sehingga menimbulkan penghambatan pertumbuhan bakteri.Senyawa fenol sebagai antibakteri adalah dengan mendenaturasi ikatan protein pada membran sel sehingga membran sel lisis dan memungkinkan fenol menembus ke dalam sitoplasma yang menyebabkan bakteri tidak berkembang.

Pada penelitian ini, dapat disimpulkan bahwa bakteri Staphylococcusaureus dapat dihambat oleh ekstrak etanol umbi Hati Tanah pada konsentrasi ekstrak terendah yaitu $1 \%$, namun perlu dilakukan penelitian lebih lanjut dengan pengujian konsentrasi yang lebih tinggi daripada yang telah diujikan sehingga akan diperoleh konsentrasi yang efektif untuk menginhibisi pertumbuhan bakteri tersebut dan dapat digunakan sebagai alternatif pilihan serta solusi dari adanya resistensi terhadap antibiotik saat ini.

\section{KESIMPULAN}

Berdasarkan hasil penelitian yang telah dilakukan, maka dapat disimpulkan bahwa :

1. Ekstrak etanol umbi Hati Tanah memiliki potensi untuk menghambat pertumbuhan bakteri Staphylococcus aureus dengan konsentrasi hambat minimum 1\%, 5\%, 10\%, dan $15 \%$.
2. Ekstrak etanol umbi Hati Tanah efektif dalam menghambat pertumbuhan bakteri Staphylococcus aureus, dalam penelitian ini pada konsentrasi $1 \%, 5 \%, 10 \%$, dan $15 \%$ ekstrak etanol umbi Hati Tanah memiliki rata-rata zona hambat berturut-turut 15,63 \pm $0,15 \mathrm{~mm}, 16,97 \pm 0,20 \mathrm{~mm}, 25,43 \pm 0,20$ $\mathrm{mm}$, dan $28,40 \pm 0,20 \mathrm{~mm}$.

\section{DAFTAR PUSTAKA}

Amalia, R. 2016. "Uji Daya Hambat Ekstrak Etanol Daun Sangkareho (Callicarpa longifolia Lam.) Terhadap Staphylococcus aureus". Palangka Raya : KTI Universitas Muhammadiyah Palangkaraya.

Clinical Laboratory Standart Institute. 2013. Performance Standart for Antimicrobial Susceptibility Testing; Twentieth Information Supplement. USA..

Haerazi, A., Dwi S. D. J., dan Yayuk A. 2016. Uji Aktivitas Antibakteri Ekstrak Kencur (Kaempferia galangal L.) Terhadap Pertumbuhan Bakteri Staphylococcus aureus dan Streptococcus viridans. Mataram : Jurnal IImiah Pendidikan Biologi "Bioscientist" Vol. 2 No. 1 Hal. 7582.

Handayani, R., Susi N., dan Widya A. V. 2015. Identifikasi Farmakognostik Tumbuhan Hati Tanah Asal Kota Palangka Raya Kalimantan Tengah.Palangka Raya : Jurnal Surya Medika Vol. 1 No. 1 Hal. 5361.

Hapsoh dan Hasanah. 2011. Budidaya Tanaman Obat dan Rempah. Medan : USU Press.

Lachman, L., Lieberman A. H., dan Kanig J. L. 1994. Teori dan Praktek Farmasi Industri II, Edisi Ketiga. Jakarta : Universitas Indonesia Press.

Lombogia, B., Fona B., dan Widdhi B. 2016. Uji Daya Hambat Ekstrak Daun Lidah Mertua (Sansevieriae 
trifasciata) Terhadap Pertumbuhan Bakteri Escherichia coli dan Streptococcus Sp. Jurnal e-Biomedik Vol. 4 No. 1 Hal. 1-5.

Mustarrichie, R., Wiwiek I., Abdul M., dan Danni R. 2016. Activity of Angiopteris evecta for Baldness Treatment. Journal of Chemical and Pharmaceutical Research Vol. 8 No. 5 Hal. 821-830.

Noorhidayah., dan Sidiyasa. 2005. Keanekaragaman Tumbuhan Berkhasiat Obat di Taman Nasional Kutai, Kalimantan Timur. Kalimantan Timur : Jurnal Analisis Kebijakan Kehutanan Vol. 2 No. 2 Hal. 115-128.

Santoso, D. 2001. Ramuan Tradisional untuk Penyakit Kulit, Edisi Kedua. Jakarta : Penebar Swadaya.

Sim dan Romi. 2009. "Kejadian Infeksi Luka Episitomi dan Pola Bakteri pada Persalinan Normal di RSUD H. Adam Malik dan RSUD $d r$. Pirngadi Medan". Medan : Tesis Universitas Sumatera Utara.

Wasitaatmadja, S. M. 1997. Penuntun IImu Kosmetik Medik. Jakarta : Universitas Indonesia Press.

Wijayakusuma, M. H. 2007. Penyembuhan dengan Temulawak. Jakarta: Sarana Pustaka Prima. 